\title{
Limited latitudinal ranging of juvenile whale sharks in the Western Indian Ocean suggests the existence of regional management units
}

\author{
Clare E. M. Prebble ${ }^{1,2, *}$, Christoph A. Rohner ${ }^{2}$, Simon J. Pierce ${ }^{2}$, David P. Robinson ${ }^{3}$, \\ Mohammed Y. Jaidah ${ }^{4}$, Steffen S. Bach ${ }^{5}$, Clive N. Trueman ${ }^{1}$ \\ ${ }^{1}$ National Oceanography Centre, University of Southampton, SO14 3ZH, UK \\ ${ }^{2}$ Marine Megafauna Foundation, Truckee, CA 96161, USA \\ ${ }^{3}$ Sharkwatch Arabia, Dubai, UAE \\ ${ }^{4}$ Qatar Ministry of Environment, PO Box 22332, Doha, Qatar \\ ${ }^{5}$ North Oil Company, PO Box 21264, Doha, Qatar
}

\begin{abstract}
Assessing the movements and connectivity of whale sharks Rhincodon typus through their range is difficult due to high individual mobility and limited knowledge of their behaviour following dispersal from coastal aggregation sites. Here, we use a large set of photo-identification and stable isotope data $\left(\delta^{15} \mathrm{~N}\right.$ and $\left.\delta^{13} \mathrm{C}\right)$ to test the assumption that sharks frequenting aggregation sites in Mozambique, Tanzania, and Qatar are a mixed stock, as inferred by genetic data. Photo-identification revealed negligible connectivity among aggregation sites and none between the southern and central areas of the Western Indian Ocean (Mozambique and Tanzania) and the Arabian Gulf (Qatar). Sight-resight data indicated that shark movements at each site could be best represented by a model that included emigration, re-immigration, and some mortality or permanent emigration. Although there was high individual variation in the isotope profiles of sharks from each location, comparison with latitudinal isotope data suggests that sharks had shown site fidelity to within a few hundred kilometres of each study area over the period of isotopic integration. Given the Endangered status of whale sharks and regional differences in anthropogenic threat profiles, further studies - and conservation assessment efforts - should consider the possibility that whale shark subpopulations exist over smaller geographical scales than previously documented.
\end{abstract}

KEY WORDS: Movement ecology $\cdot$ Planktivore $\cdot$ Philopatry $\cdot$ Elasmobranch $\cdot$ Mark-recapture

\section{INTRODUCTION}

Successful species conservation requires an accurate assessment of ecological connectivity among geographically separated subpopulations (Worboys et al. 2010, Dubois et al. 2016). If a change in environmental or anthropogenic circumstances threatens a species in a particular location, this should be considered with reference to the entire geographical range inhabited by the species (Juinio-Meñez 2015). If a subpopulation is truly isolated, any local threat

\footnotetext{
*Corresponding author: cemp1g14@soton.ac.uk
}

may result in decline and local extinction (Johnson et al. 2015), while interconnectivity means that emigration and an eventual shift in area utilisation could occur instead (Lima et al. 1996). Temporal aspects to connectivity also exist. A subpopulation can still decline to local extinction, even if genetic connectivity exists on a long-term, multi-generational timescale, in the face of a fast-acting threat (Ciach 2015). Hence it is important to examine both the long-term (genetic) and short-term (ecological, subpopulation-level) connectivity. Investigating the

() The authors 2018. Open Access under Creative Commons by Attribution Licence. Use, distribution and reproduction are unrestricted. Authors and original publication must be credited. 
spatial ecology of a species can indicate where functional population units and movement corridors may require specific management (de la Torre et al. 2016).

Marine populations are commonly structured as a 'metapopulation', where loosely connected subpopulations are linked by the exchange of individuals (Dubois et al. 2016). Understanding this connectivity continues to be a major focus for highly mobile marine species, as large spatial scales often need to be considered for their management (Hays et al. 2016). The movement ecology of the whale shark Rhincodon typus Smith, 1828, the world's largest fish, has proven to be a complex topic. Whale sharks are predictably observed in a small number of specific coastal areas and islands scattered through the tropics and subtropics (Rowat \& Brooks 2012, Rohner et al. 2015a), where in many cases they are clearly targeting ephemeral bursts of productivity (Rowat \& Brooks 2012). However, only certain life-stages tend to be present at these sites, with local population structure typically biased towards juvenile males (Rohner et al. 2015b, Robinson et al. 2016)

Whale sharks have been targeted by fisheries in several countries (Pravin 2000, Anderson \& Waheed 2001, Alava et al. 2002, Hsu et al. 2012), which has led to significant population decline and a 2016 'Endangered' listing on the IUCN Red List for both the Indo-Pacific (IO) subpopulation and the global population, and listings on Appendix II of both the Convention on International Trade of Endangered Species and the Convention on Migratory Species (Pierce \& Norman 2016). Whale sharks are longlived, slow-growing, and late to mature (Hsu et al. 2012) and as such are particularly vulnerable to other human threats, such as boat strikes and non-targeted catches in gillnet and tuna purse-seine fisheries (Speed et al. 2008, Pierce \& Norman 2016). Though several countries offer national or territory-level management measures for whale sharks (Pierce \& Norman 2016), the species remains unprotected in most Western Indian Ocean (WIO) range states, including the 3 countries explicitly considered in this study (Mozambique, Tanzania and Qatar). At the same time, however, swimming and diving with whale sharks is a multi-million dollar tourism industry and is popular within several WIO countries (Jones et al. 2009, Pierce et al. 2010, Cagua et al. 2014, Ziegler et al. 2016).

The Western Indian Ocean region is a global stronghold for whale sharks with several identified coastal and offshore aggregations (e.g. Cliff et al. 2007, Rowat et al. 2011, Robinson et al. 2013, Rohner et al. 2015a). Broadly speaking, WIO coastal sites are classically dominated by juvenile male whale sharks, with larger individuals assumed to favour more offshore habitats as seen in the Atlantic and Pacific Oceans (Borrell et al. 2011, Robinson et al. 2013, Clingham et al. 2016, Ramírez-Macías et al. 2017). Large-scale population genetics studies on whale sharks have found no defined structure within the Indo-Pacific region, indicating that such aggregations are broadly connected over evolutionary time scales (Schmidt et al. 2007). However, over shorter periods, connectivity studies using photo-identification (Brooks et al. 2010, Andrzejaczek et al. 2016, Norman et al. 2017) and satellite tags (Berumen et al. 2014, Vignaud et al. 2014, Robinson et al. 2017) in this region have found minimal connectivity between these areas.

Photo-ID is routinely used for monitoring whale shark population structure, abundance and connectivity (Graham \& Roberts 2007, Holmberg et al. 2009, Brooks et al. 2010, Norman et al. 2017). The unique and stable skin colouration pattern of whale sharks (Arzoumanian et al. 2005, Marshall \& Pierce 2012) allows individual sharks to be identified and re-identified over decadal time-scales (Norman et al. 2017). Photo-ID also represents a comparatively simple and inexpensive means of sampling a large number of individual sharks (Robinson et al. 2016, Norman et al. 2017). However, there is significant spatial bias in most whale shark photo-ID datasets, as studies often focus on aggregation sites where whale sharks may be readily seen, but in which they may spend a relatively small proportion of their time (Rowat et al. 2009, 2011, Fox et al. 2013). Although maximum likelihood methods can be used to account for temporal variation of effort in the data (Whitehead 2001), whale sharks are typically not available for 'visual recaptures' outside aggregation sites in which there is either dedicated research or citizen science activity (Cagua et al. 2015). When considering populationlevel connectivity, then, it is prudent to combine these photo-ID data with a sightings-independent method.

Biochemical 'tags' offer a cost-effective complement to other methodological approaches. The ratio of heavy and light stable isotopes of certain elements vary spatially within ecosystems (Hobson 1999). Stable isotope composition of nitrogen and carbon (expressed as $\delta^{15} \mathrm{~N}$ and $\delta^{13} \mathrm{C}$ values, respectively) are typically used in the marine environment as they vary dynamically in space and time (Graham et al. 2010, Trueman et al. 2012). These isotopic gradients can be mapped over a range of geographic scales to 
produce 'isoscapes' (Graham et al. 2010). The isotopic composition of baseline production is transferred through the food web in a predictable manner, allowing the retrospective assignment of consumers' feeding areas (McMahon et al. 2013, Trueman et al. 2017). Isotopes are therefore useful in residency and movement studies, as it is a reflection of the location of their food sources (Graham et al. 2010).

This study tests the hypothesis that predominantly juvenile and/or male whale shark aggregations are localised and show low connectivity between 3 major whale shark aggregations in the Western Indian Ocean: Tofo Beach, Inhambane province, in southern Mozambique; $\sim 1800 \mathrm{~km}$ north, at Kilindoni Bay, Mafia Island, Tanzania; and $\sim 4000 \mathrm{~km}$ north again, to Al Shaheen oil field off Qatar in the Arabian Gulf (Fig. 1). The population ecology of whale sharks in these 3 study areas has been previously documented. The Inhambane coast hosts 4 to $9 \mathrm{~m}$ total length (TL) sharks, biased towards males $(74 \%$ ) (Haskell et al. 2015, Rohner et al. 2015). Whale sharks here appear to preferentially use productive coastal waters (Rohner et al. 2018). A significant decline in sightings
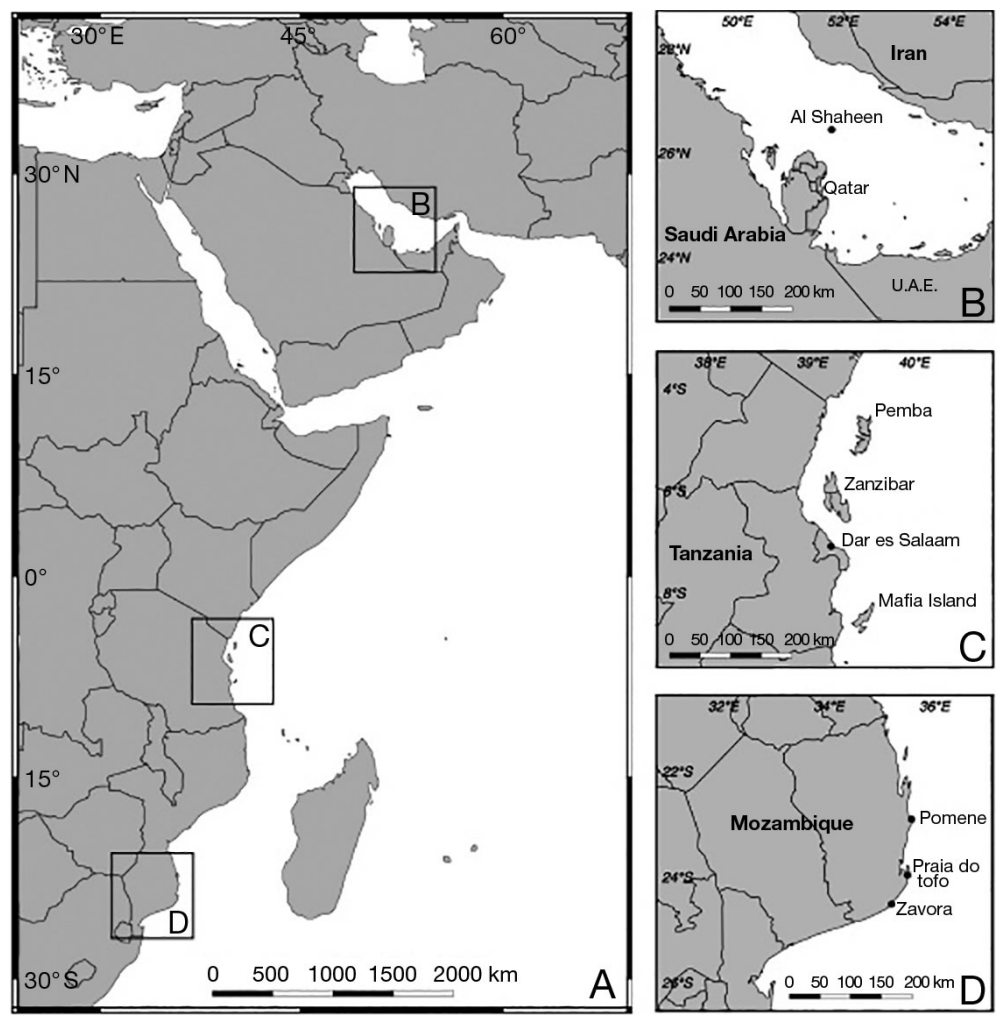

Fig. 1. East coast of Africa and Arabian Sea. (A) The position of our 3 study sites in the western Indian Ocean; (B) the Al Shaheen whale shark aggregation in the Arabian Gulf; (C) Mafia Island off the coast of Tanzania; and (D) Praia do Tofo on the coast of southern Mozambique occurred in the Tofo Beach area between 2005 and 2011 (Rohner et al. 2013b) and appears to have continued until 2016 (Pierce \& Norman 2016). Mafia Island is home to a smaller group of resident whale sharks (Cagua et al. 2015). Population structure here is similar to that in Mozambique, with a bias towards male sharks (89\%) and a size range of 4 to $10 \mathrm{~m} \mathrm{TL}$ (Rohner et al. 2015). The Qatar aggregation is around $90 \mathrm{~km}$ offshore (Robinson et al. 2013, 2016, 2017). Photo-ID and sat-tagging studies have concluded that these sharks are largely resident to the Arabian Gulf and Gulf of Oman and are predominantly mature males (Robinson et al. 2016, 2017). Median male TL at Al Shaheen is larger (8 $\mathrm{m}$ ) than in Mozambique or Tanzania, with more mature individuals present, although the overall size range is similar at 4 to $10 \mathrm{~m}$ TL (Robinson et al. 2016).

Here, we use a large set of photo-ID and stable isotope data to test the assumption that the sharks frequenting these 3 separate aggregation sites are a separate management stock. We demonstrate that there are significant differences in stable isotope ratios and minimal connectivity among sites, with a pronounced differentiation between sharks in the southern and central areas of the WIO (Mozambique and Tanzania), and those from the Arabian Gulf (Qatar).

\section{MATERIALS AND METHODS}

\section{Study areas}

This study was conducted in 3 whale shark aggregation sites: (1) off Tofo Beach, Mozambique (235' $\left.\mathrm{S}, 35^{\circ} 33^{\prime} \mathrm{E}\right)$, Mozambique (see Pierce et al. 2010, Rohner et al. 2013a,b, 2015, Haskell et al. 2015); (2) Kilindoni Bay, Mafia Island, Tanzania $\left(7.29^{\circ} \mathrm{S}, 39.65^{\circ} \mathrm{E}\right.$ ) (see Cagua et al. 2015, Rohner et al. 2015a,b); and (3) the $\mathrm{Al}$ Shaheen oil field, $90 \mathrm{~km}$ off the coast of Qatar in the Arabian Gulf $\left(26.6^{\circ} \mathrm{N}, 51.9^{\circ} \mathrm{E}\right.$ ) (Robinson et al. 2013, 2016) (Fig. 1). Photo-ID and stable isotope data were collected at all 3 sites. Stable isotope data were compared to known isotopic gradients in the Western Indian Ocean using data from goose barnacles Lepas anatifera (Lorrain et al. 2015) along with yellowfin Thunnus albacares and skipjack tuna Katsuwonus pelamis (Sardenne et al. 2016). 


\section{Photo-identification}

Individual whale sharks were identified using underwater photographs of the body region immediately posterior to the gills (Arzoumanian et al. 2005). These images were uploaded, processed using a pattern-matching algorithm to identify individual sharks, and stored on the online database, Wildbook for Whale Sharks (www.whaleshark.org). Each 'encounter' is here defined as 1 sighting per identified shark per day. Estimated total length $(\mathrm{TL}, \mathrm{cm})$ and sex were determined (based on the presence or absence of claspers, as per Rohner et al. 2015a) where possible. Data were from the earliest encounter record for each study site until 31 December 2015. Neither standardised nor concurrent sampling across the sites were possible due to differences in the seasonality and accessibility of the aggregations.

The Wildbook for Whale Sharks database was used to obtain the total number of encounters and identified individuals for each study site along with sex and size metadata. Pairwise comparisons were made between each of the study sites to identify individuals that had been identified in both. Sighting data were used to assess the lagged identification rate (LIR) within study sites (Whitehead 2001). LIR represents the probability of re-sighting identified individuals over increasing time periods, here measured in days (Whitehead 2001). Eight models of lagged identification, each representing a hypothetical population with varying combinations of immigration, emigration, re-immigration, and mortality were fitted to the empirical data (see the Appendix). The Akaike information criterion (AIC), or quasi-AIC (QAIC) for overdispersed data, was used to compare these models to identify the best fit at each site (Whitehead 2009). Parameter estimates with 95\% CI and SE were generated for LIR by bootstrapping data 100 times (Buckland \& Garthwaite 1991). These analyses were conducted using the movement module in SOCPROG 2.6 (Whitehead 2009). These were the first calculations of this kind for the Tanzanian and Mozambican aggregations, and updated previous calculations from Qatar (Robinson et al. 2016) with 2015 sightings data (an additional 192 encounters).

\section{Biopsy sample collection and chemical analysis}

Biopsies of live, unrestrained whale sharks were taken in Mozambique (2011 to 2013), Tanzania (2012 to 2014), and Qatar (2012 to 2014) (Table 1). First, sharks were individually identified and sexed (as above). Samples were taken using a hand spear with a modified tip that extracted biopsies laterally from between the first and second dorsal fins. Samples were stored on ice in the field. Upon the recommendation of multiple elasmobranch isotope studies, including whale sharks (Hussey et al. 2012a, Kim \& Koch 2012, Li et al. 2016, Burgess \& Bennett 2017, Marcus et al. 2017), samples were rinsed in fresh water upon return to remove contaminants and excess urea. The upper dermal denticle layer was then separated from the white connective tissue layer in each sample. This deeper connective tissue layer was frozen onsite and used for all further analyses. We also collected muscle samples from local, non-migratory, planktivorous fishes in Mozambique and Tanzania to represent isotopic conditions at the collection site. This was not possible in Qatar. All samples were from halfbeak Hemiramphus spp. fish. A total of 10 samples were collected from Tanzania and 9 from Mozambique.

Samples were kept frozen and transported to the University of Southampton, UK, where they were freeze-dried and homogenised prior to analysis in an EA 1110 elemental analyser linked to a Europa Scientific 2020 isotope ratio mass spectrometer at OEA Laboratories Cornwall. Raw data were corrected using the reference materials USGS40 and USGS41 (glutamic acid from USGS, Reston, USA). An internal QC material bovine liver standard (NIST 1477a) was used to monitor the precision of the instrument. Precision was on average $0.21 \%$ for both $\mathrm{C}$ and $\mathrm{N}$.

Isotope ratios are expressed \%o deviations from the reference materials VPDB and air for $\delta^{13} \mathrm{C}$ and $\delta^{15} \mathrm{~N}$ values, respectively.

Table 1. Number of whale shark samples collected of each sex (male, female) and unknown sex (UK) at each study site, and the number of repeat samples taken from identified and unidentified (ID UK) individuals, and the estimated total length (TL): range (mean $\pm \mathrm{SD}$ )

\begin{tabular}{|lccccccc|}
\hline Site & Males & Females & Sex UK & ID UK & Repeats & Total & TL (cm) \\
\hline Mozambique & 40 & 8 & 2 & 0 & 18 & 68 & $500-800(608 \pm 79)$ \\
Tanzania & 61 & 13 & 4 & 9 & 110 & 188 & $500-900(712 \pm 117)$ \\
Qatar & 22 & 4 & 1 & 9 & 10 & 48 & $400-800(597 \pm 99)$ \\
\hline
\end{tabular}


Elemental C:N ratios for water washed whale shark connective tissue shark samples were similar and relatively low in each study site (Mozambique: [mean \pm SD] $2.65 \pm 0.24$, Qatar: $2.94 \pm 0.24$, Tanzania: $2.89 \pm$ 0.26) and matched lipid extracted $\mathrm{C}: \mathrm{N}$ ratios for similar tissues from Australian whale sharks (Marcus et al. 2017). No chemical treatment was undertaken to remove lipids, and analytical results were not adjusted to correct for lipid contents. During the sampling period we collected more than 1 , and up to 4 samples, from 0 to $1063 \mathrm{~d}$ apart. The first sample of every individual was analysed. Then, assuming a half-life (isotope turnover rate) of $30 \mathrm{~d}$, we also kept any samples from the same individuals that were taken greater than 5 half-lives (>150 d) after the initial sample. After 5 half-lives the sample would then contain only $~ 3 \%$ of the sample before and can thus be considered independent. Planktivore samples from Tanzania had high enough $\mathrm{C}: \mathrm{N}$ values to merit mathematical lipid correction (Post et al. 2007) (mean \pm SD; $3.52 \pm 0.2$ ), while Mozambican planktivore samples did not (3.1 \pm 0.04). Lipid removal is a complex, species- and tissuespecific issue in stable isotope analysis (Post et al. 2007). As it was not possible within this study to calculate pre- and post-lipid removal values for each sample type, we applied a lipid correction factor to the bulk Tanzania planktivore $\delta^{13} \mathrm{C}$ data (Kiljunen et al. 2006). To assess within-sample variance in whale shark tissues, we ran 5 repeat samples from the same biopsy for 3 individuals: 2 from Mozambique (Wildbook IDs MZ-013 and MZ-607) and 1 from Qatar (Q-073).

\section{Stable isotope analysis}

Differences and patterns between study sites were investigated for $\delta^{15} \mathrm{~N}$ and $\delta^{13} \mathrm{C}$ bulk values. The mean, standard deviation, and range of $\delta^{15} \mathrm{~N}, \delta^{13} \mathrm{C}$, and estimated TL values for each study site were calculated. All data were tested for normality using a ShapiroWilk test. Bartlett's test was used to compare homogeneity of variance between the study sites. Within-sample variance of the 3 chosen samples was compared to overall variance at each site. Box, residuals, and $\mathrm{Q}-\mathrm{Q}$ plots were created to visualise any outliers and patterns in variance. ANOVA (normally distributed data) or Kruskal-Wallis (non-normally distributed data) tests were then performed on data to examine between site, between sex, and TL differences. Any missing values for sex or estimated TL were not included in the analysis. Post-hoc Tukey HSD (normally distributed data) or Nemenyi (non-normally distributed data) tests were used to explore the pairwise comparisons with significant $p$-values. Linear regression models were applied to test the effects of estimated TL on $\delta^{15} \mathrm{~N}$ and $\delta^{13} \mathrm{C}$ values.

Published and established isotopic gradients in the Western Indian Ocean were used to spatially assess the whale shark isotope data. $\delta^{15} \mathrm{~N}$ and $\delta^{13} \mathrm{C}$ isotopic data from yellowfin tuna Thunnus albacares and skipjack tuna Katusuwonus pelamis were taken from Sardenne et al. (2016). Barnacle $\delta^{15} \mathrm{~N}$ data from Lorrain et al. (2015) were used as a proxy for $\delta^{15} \mathrm{~N}$ baseline values across latitude. For a generalised representation of baseline values of $\delta^{13} \mathrm{C}$ across latitude, we extracted predicted bulk phytoplankton $\delta^{13} \mathrm{C}$ values from an isotopic extension to the NEMO-medusa global biogeochemical model (Magozzi et al. 2017). Model data were averaged by latitude in $5^{\circ}$ increments from $30^{\circ} \mathrm{S}$ to $30^{\circ} \mathrm{N}$ in this region.

A tissue conversion factor (dermal connectivemuscle) was applied to the bulk whale shark data to allow for direct comparisons to the tuna and barnacle isotope values. We used a figure of $-2.5 \%$ for $\delta^{13} \mathrm{C}$ values. This figure was arrived at after consideration of results from tissue comparisons of an ecologically similar species, the reef manta ray Mobula alfredi (Couturier et al. 2013), paired samples from the bluespotted mask ray Neotrygon kuhlii (Burgess \& Bennett 2016), and results from this study for 3 whale shark samples that contained both muscle and dermal connective tissue (Table 2). As the sample sizes for these
Table 2. Comparison of (mean $\pm \mathrm{SD}$ ) bulk isotope values for all muscle and dermal connective tissue per species. Mean isotopic difference between muscle and skin tissue types and the range given the calculated SD. Mobula alfredi (Couturier et al. 2013), Neotrygon kuhlii (Burgess \& Bennett 2017) and whale shark Rhinocodon typus (results from this study)

\begin{tabular}{|lccc|}
\hline & M. alfredi & N. kuhlii & R. typus \\
\hline Muscle (n) & 11 & 5 & 4 \\
Skin (n) & 6 & 5 & 4 \\
$\boldsymbol{\delta}^{\mathbf{1 3}} \mathbf{C}$ & & & \\
Muscle & $-17.4 \pm 0.49$ & $-14.38 \pm 1.13$ & $-16.35 \pm 1.47$ \\
Skin & $-14.55 \pm 0.81$ & $-12.1 \pm 1.38$ & $-13.86 \pm 1.52$ \\
Difference & $-2.85(-1.55$ to -4.15$)$ & $-2.28(-4.79$ to 0.23$)$ & $-2.49(-5.48$ to 0.5$)$ \\
$\boldsymbol{\delta}^{\mathbf{1 5}} \mathbf{N}$ & & & \\
Muscle & $8.95 \pm 1.1$ & $12.34 \pm 1.07$ & $11.14 \pm 1.14$ \\
Skin & $8.89 \pm 1.09$ & $13.64 \pm 1.07$ & $9.73 \pm 1.2$ \\
Difference & $0.06(-2.13$ to 2.25$)$ & $-1.3(-3.46$ to 0.86$)$ & $1.42(-0.91$ to 3.75$)$ \\
\hline
\end{tabular}


species were all small, we also considered published values for silky Carcharhinus falciformis and blue sharks Prionace glauca (Li et al. 2016), currently the only study that compares band muscle tissue in sharks.

Elasmobranch skin tissue is comprised of many layers of collagen fibre bundles, particularly in the dorsal region where they support the fins (Meyer \& Seegers 2012, Motta 2012). The major amino acid in the type I collagens found in shark skin is glycine, a non-essential amino acid which is typically ${ }^{13} \mathrm{C}$ enriched compared to bulk protein (McMahon et al. 2010). Consequently collagen is typically enriched in ${ }^{13} \mathrm{C}$ (i.e. shows more positive $\delta^{13} \mathrm{C}$ values) than muscle protein by approximately 3 to $5 \%$ (Satterfield \& Finney 2002). The offset to connective tissue here is much smaller than pure collagen, roughly $-2.5 \%$. Whale shark, manta, and masked ray dermal connective tissues either contain a lower percentage of collagen, or we are seeing temporal effects where these tissues are integrating a change in diet at different rates. Even though the data is limited and uncontrolled, the ranges of the offsets between individuals of $\delta^{13} \mathrm{C}$ are still small (Table 3), suggesting the offset is remarkably consistent across individuals. $\delta^{15} \mathrm{~N}$ values in collagen are generally indistinguishable from muscle, meaning any offset is likely a result of temporal effects.

To visually compare the isotopic niche of the whale sharks, we calculated Bayesian ellipses and convex hulls for each study site (Jackson et al. 2011). We used small sample size-corrected Bayesian ellipses within the SIEBER package to account for potential bias between different sample sizes. Second-order polynomial regression models were applied to all

Table 3. Difference between muscle and dermal connective tissue bulk isotope values for paired samples only. Values in bold are mean \pm SD (Couturier et al. 2013, this study)

\begin{tabular}{|ccccc|}
\hline & \multicolumn{2}{c}{ Neotrygon kuhlii } & \multicolumn{2}{c|}{ Rhincodon typus } \\
& ID & Difference & ID & Difference \\
\hline $\boldsymbol{\delta}^{\mathbf{1 3}} \mathbf{C}$ & 8SIA & -2.7 & Q118 & -3.1 \\
& 10SIA & -2.5 & Q125 & -2.65 \\
& 18SIA & -1.4 & TZ-009 & -2.33 \\
& 27SIA & -2.2 & & \\
& 32SIA & -2.6 & & \\
& & $-\mathbf{2 . 2 8} \pm \mathbf{0 . 5 3}$ & & $\mathbf{- 2 . 6 9} \pm \mathbf{0 . 3 9}$ \\
$\boldsymbol{\delta}^{\mathbf{1 5}} \mathbf{N}$ & 8SIA & -1.2 & Q118 & 2.33 \\
& 10SIA & -1.8 & Q125 & 1.58 \\
& 18SIA & -1.5 & TZ-009 & 1.58 \\
& 27SIA & -0.8 & & \\
& 32SIA & -1.2 & & $\mathbf{1 . 8 3} \pm \mathbf{0 . 4 4}$ \\
& & $\mathbf{- 1 . 3} \pm \mathbf{0 . 3 7}$ & & \\
\end{tabular}

datasets to visualise, evaluate and compare latitudinal trends. All statistical calculations were conducted using the statistics platform R (R Development Core Team 2013).

\section{RESULTS}

\section{Photo-identification}

A total of 4197 encounters and 1240 individual sharks were recorded across all sites over the study period. Most encounters $(\mathrm{n}=2027)$ and individuals ( $\mathrm{n}=664$ ) were recorded in Mozambique. Tanzania had the fewest identified individuals $(\mathrm{n}=139)$, but a comparatively high number of encounters $(n=1282)$. Qatar had over double the number of identified individuals as Tanzania ( $\mathrm{n}=437$ ), but with fewer encounters logged $(\mathrm{n}=482)$. Tanzania had the highest re-sighting rate with $71 \%$ of individuals seen on multiple sampling days, followed by Mozambique (53\%), and Qatar (46\%). Tanzania had the highest percentage that were seen in multiple years $(55 \%)$, followed by Mozambique (44\%), and Qatar (35\%). All 3 aggregations were male-dominated, with similar size distributions in Mozambique and Tanzania, and larger more mature sharks in Qatar (Table 4). Qatar sharks had the largest mean $( \pm \mathrm{SD}) \mathrm{TL}(714 \pm 116 \mathrm{~cm})$, with Tanzania $(603 \pm 94 \mathrm{~cm}$ ) and Mozambique $(605 \pm$ $76 \mathrm{~cm}$ ) having smaller and similar mean TLs. Sharks from Qatar were significantly larger than individuals from Tanzania $(\mathrm{p}<0.001)$ and Mozambique $(\mathrm{p}<$ $0.001)$ overall. There was no significant difference between sharks from Mozambique and Tanzania $(p=0.99)$. Only 2 individual sharks were recorded in more than 1 aggregation site in this study, both moving between Mozambique and Tanzania, representing $0.25 \%$ of the total identified population of both sites. Individuals MZ-129 and MZ-136 were both first identified in Mozambique, yet both have more numerous and more recent encounters logged in Tanzania (Table 5). Neither shark has been seen in Mozambique following the first sighting in Tanzania. While not explicitly considered in this study, use of Wildbook for Whale Sharks meant that sharks in these 3 study areas were also available for matching with other countries in the WIO region from which sharks have been submitted. Matches were found between the Tofo area in Mozambique and South Africa $(n=24)$, representing $49 \%$ of all whale sharks identified in South Africa, and between Al Shaheen and Oman $(\mathrm{n}=9)$, representing $10 \%$ of all sharks identified in Oman. 


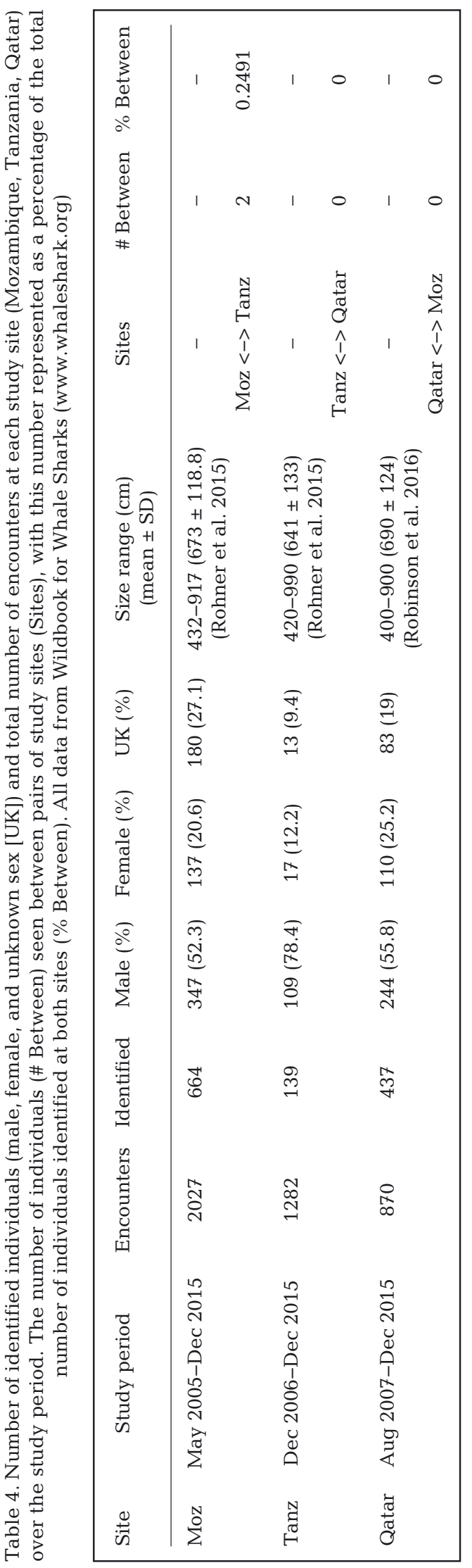

Table 5. Total sighting records per year of the only 2 individuals recorded in both Mozambique and Tanzania. Solid line signifies the period between 2007 and 2012 during which neither shark was sighted at either study site

\begin{tabular}{|lccc|cccc|}
\hline Site & Shark ID & 2006 & 2007 & 2012 & 2013 & 2014 & 2015 \\
\hline Moz & MZ-129 & 1 & 1 & 3 & & & \\
& MZ-136 & 1 & & & & & \\
Tanz & MZ-129 & & & & 3 & 5 & 4 \\
& MZ-136 & & & 3 & 3 & 7 & 3 \\
\hline
\end{tabular}

Modelled LIR for sharks sighted in Tanzania steeply declined from Day $\sim 1$ to Day $\sim 136$, down to a LIR of 0 , then jumped up again at Day $\sim 256$, followed by another gradual decline (Fig. 2). The 0 value at Day 188 is an artefact of the seasonal sampling regime rather than an indication of periodic returns to the area. The best-fit model in all cases included immigration, emigration, and mortality, and for the Tanzanian data, contained an estimated (mean \pm SE) $34.78 \pm 3.62$ sharks (CI 26.5 to 39.7) within the Mafia aggregation on any given day. The estimated mean residency time in the area was (mean $\pm \mathrm{SE}$ ) $30.63 \pm 11.18 \mathrm{~d}$ (CI 10.4 to 49.0 ), with a mean time out of the area of $23.9 \pm 8.3 \mathrm{~d}$ (CI 10.6 to 44.7 ), and a mortality rate of (mean $\pm \mathrm{SE}$ ) $0.0003 \pm 0.00009$ (CI 0.0001 to 0.0004 ).

Modelled LIR for sharks sighted in Mozambique steeply declined from Day $\sim 1$ to Day $\sim 16$, then gradually declined to approach 0 at over Day 4000 (Fig. 2). The best-fit model for Mozambique was based on QAIC as opposed to AIC values as there was over-dispersion in these data. The model produced an estimate of (mean \pm SE) $50.6 \pm 11.8$ sharks (CI 30.6 to 68.5 ) within the study area on an average day. The mean residency time in the area was (mean $\pm \mathrm{SE}$ ) $9 \pm 5.03 \mathrm{~d}$ (CI 3.21 to 20.9), with mean time out of the area of $29.9 \pm 10.1 \mathrm{~d}$ (CI 15.3 to 48.7 ) and a mortality rate of (mean \pm SE) $0.0006 \pm 0.00009$ (CI 0.0005 to 0.0008 ).

Modelled LIR for sharks sighted in Qatar steeply declined from Day $\sim 1$ to Day $\sim 64$, with a slight increase between Day 64 and Day $\sim 256$, where there is a secondary peak, followed a gradual decline beyond Day $\sim 1025$ (Fig. 2). The best fit model contained an estimated (mean $\pm \mathrm{SE}$ ) $115.9 \pm 17.7$ sharks (CI 83.8 to 151 ) in the aggregation at any one time. The mean residency time in the area was (mean \pm SE) $17.5 \pm 9.6 \mathrm{~d}$ (CI 7.00 to 42.2 ), with a mean time away from the area of $37.54 \pm 15.7 \mathrm{~d}$ (CI 19.3 to 78.3 ), and a mortality rate of (mean \pm SE) $0.0004 \pm$ 0.0001 (CI 0.0002 to 0.0007 ).

\section{Stable isotope analysis}

The stable isotope compositions of all individuals are shown in Fig. 3. Isotopic niche areas (Jackson et al. 2011) show some separation by site although there is partial overlap of the 


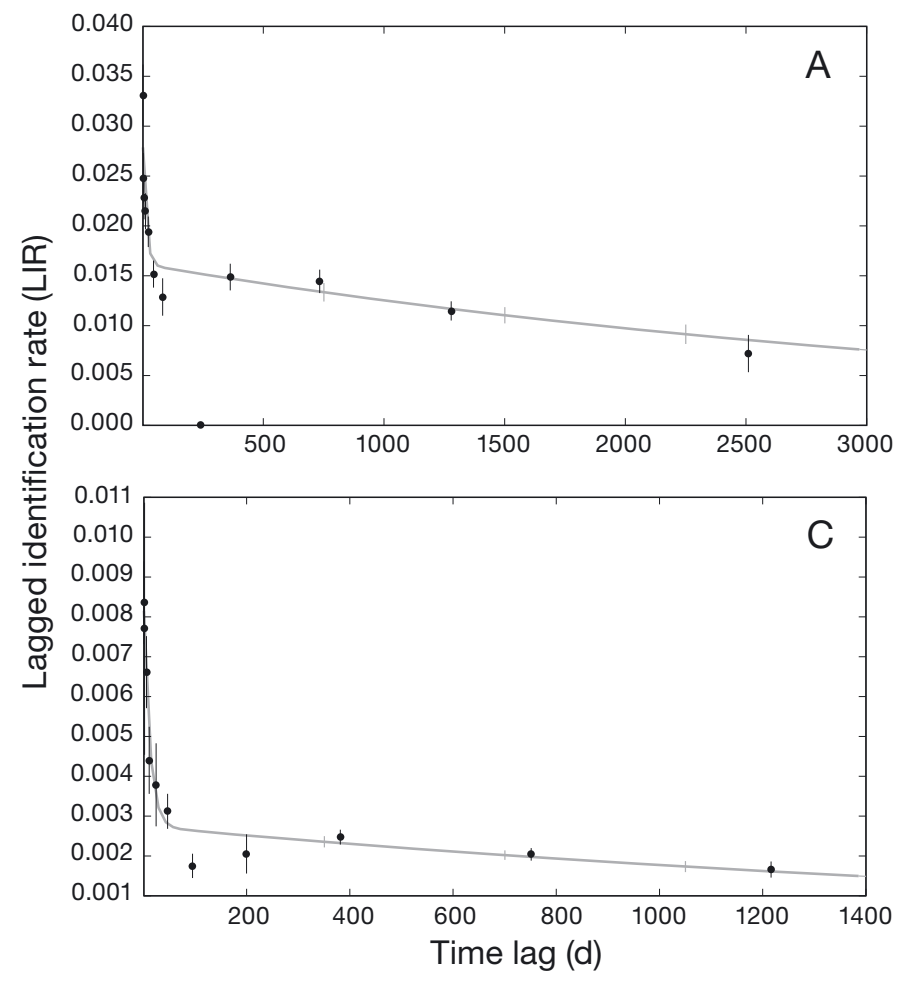

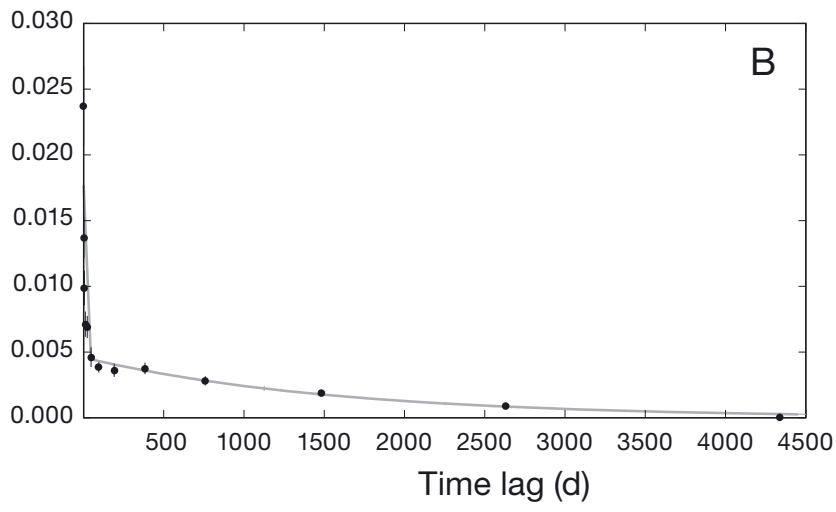

Fig. 2. Lagged identification rates (mean $\pm \mathrm{SE}$ ) for whale sharks in (A) Tanzania, (B) Mozambique, and (C) Qatar, modelled from fitted emigration + remigration + mortality rate. See Appendix

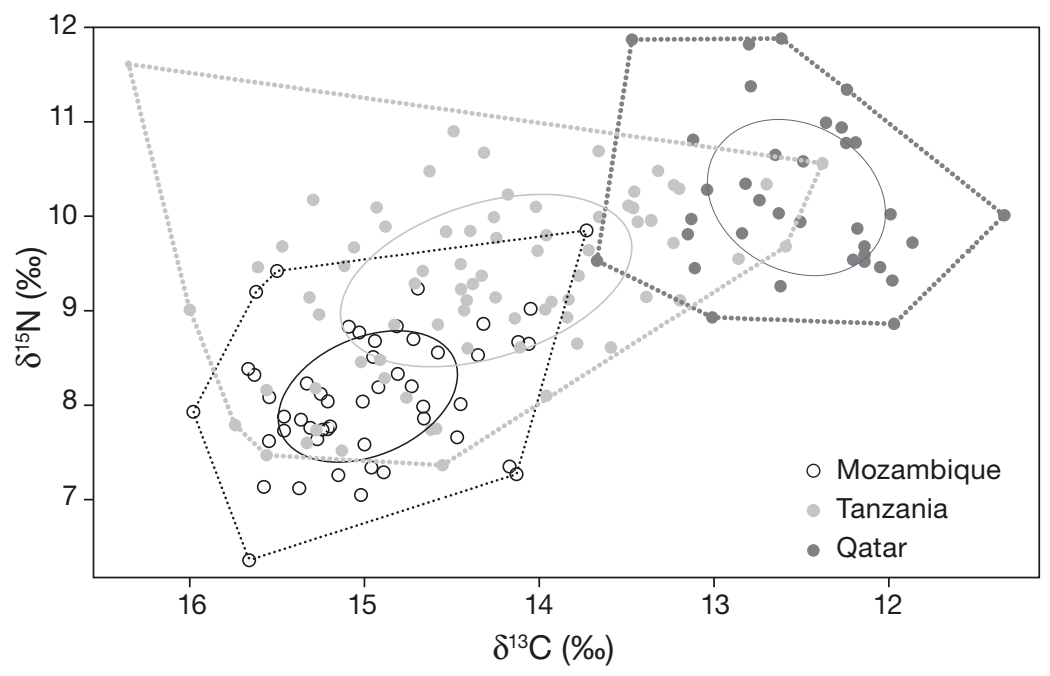

Fig. 3. Biplot of $\delta^{15} \mathrm{~N}$ and $\delta^{13} \mathrm{C}$ values (mean $\pm \mathrm{SD}$ ) by study site. Ellipses show $40 \%$ standard ellipses, polygons show convex hulls

Mozambique and Tanzania ellipses. Mean whale shark dermal connective tissue $\delta^{15} \mathrm{~N}$ values increased from Mozambique (mean $\pm \mathrm{SD} ; 8.1 \pm 0.5 \%$ ) to Tanzania $(9.4 \pm 0.8 \%$ ) , and Qatar $(10.2 \pm 0.8 \%$ ), and the range in $\delta^{15} \mathrm{~N}$ values was similar between sites (between 3 and $4.2 \%$ ). Mean $( \pm \mathrm{SD}) \delta^{13} \mathrm{C}$ values in shark dermal connective tissues also increased with latitude: Mozambique $(-15 \pm 0.3 \%)$, Tanzania $(-14.3 \pm$ $0.7 \%)$, and Qatar $(-12.6 \pm 0.2 \%)$. The range of $\delta^{13} \mathrm{C}$ was similar for Mozambique $(2.3 \%$, range $=-16$ to $-13.7 \%$ ) and Qatar $(1.8 \%$, range $=-13.7$ to $-11.9 \%)$, but sharks from Tanzania were more variable in $\delta^{13} \mathrm{C}$ values $(4 \%$, range $=-16.4$ to $-12.4 \%$ ).

All $\delta^{15} \mathrm{~N}$ data were normal (Mozambique Shapiro-Wilk $p=0.2$, Tanzania $\mathrm{p}=0.1$, Qatar $\mathrm{p}=0.07$ ), with equal variance between sites (Bartlett $\mathrm{p}=$ 0.1). $\delta^{13} \mathrm{C}$ data were normal for Tanzania (Shapiro-Wilk $\mathrm{p}=0.9$ ), but nonnormal for Mozambique $(\mathrm{p}<0.05)$ and Qatar ( $p=0.02$ ). Boxplots of $\delta^{13} \mathrm{C}$ by study site identified 3 obvious outliers: 2 from Qatar (3 and 2.7 SD from the mean), and 1 from Mozambique (4.6 SD from the mean), driving the nonnormal result (Fig. 4). There were no patterns in residuals or variance. We tested the data using ANOVA including the outliers as $\delta^{13} \mathrm{C}$ values also had equal variance between sites (Bartlett's $\mathrm{p}=$ 0.1) despite the violation of normality (Underwood 1997). We also tested the data omitting the outliers where $\delta^{13} \mathrm{C}$ data were then normal for all sites: Mozambique (Shapiro-Wilk p = 0.2), Tanzania (Shapiro-Wilk $\mathrm{p}=0.9$ ), and Qatar (Shapiro-Wilk $\mathrm{p}=$ $0.7)$. ANOVA results were significant with and with- 


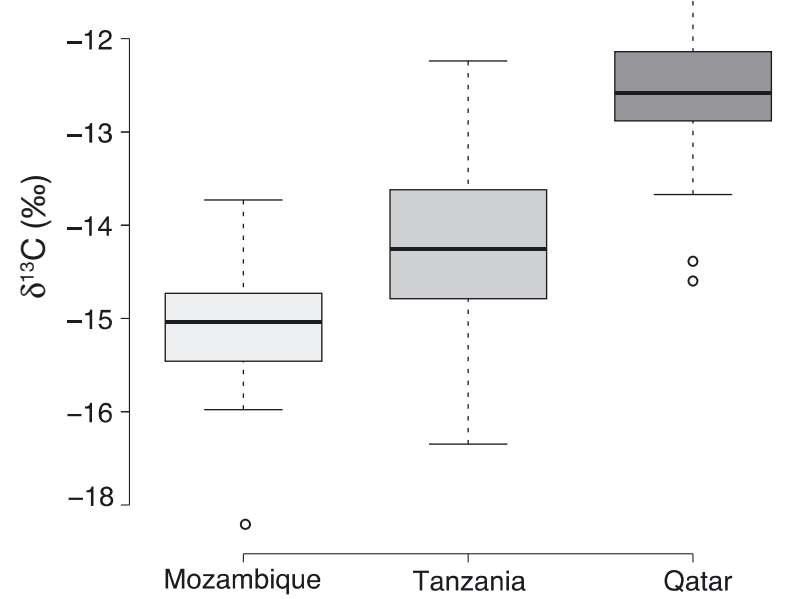

Fig. 4. $\delta^{13} \mathrm{C}$ separated by study site. The central box spans the interquartile range, the middle line denotes the median, and the whiskers above and below shoe the maximum and minimum values. Outliers are shown as circles

out these outliers, given this and the large deviations from the mean, these 3 points are therefore addressed separately, and omitted from further analysis to uphold the terms of normality.

Mean $\delta^{15} \mathrm{~N}$ and $\delta^{13} \mathrm{C}$ values were significantly different between sites (ANOVA: $F_{2,218}=68 ; \mathrm{p}<0.001$, ANOVA: $\left.F_{2,218}=121 ; \mathrm{p}<0.001\right)$, respectively. Tukey HSD test results for $\delta^{15} \mathrm{~N}$ and $\delta^{13} \mathrm{C}$ values were significant for all pairwise comparisons, with $\mathrm{p}<0.001$. There were no overall differences between the sexes for $\delta^{15} \mathrm{~N}$ (ANOVA: $F_{2,206}=1.7: \mathrm{p}=0.2$ ) or $\delta^{13} \mathrm{C}$ (ANOVA: $F_{2,206}=3.7: \mathrm{p}=0.3$ ). Estimated total length had a significant effect on both $\delta^{15} \mathrm{~N}\left(\mathrm{R}^{2}=0.08, \mathrm{df}=\right.$ $199, \mathrm{p}<0.001)$ and $\delta^{13} \mathrm{C}$ values $\left(\mathrm{R}^{2}=0.23, \mathrm{df}=199\right.$, $\mathrm{p}<0.001$ ), with larger shark dermal connective tissue being more enriched in ${ }^{15} \mathrm{~N}$ and ${ }^{13} \mathrm{C}$. However, there was a low explanatory power for both models. There was also a significant effect of study site on estimated total length (Kruskal-Wallis: $\chi^{2}[25.9], \mathrm{p}<0.001$ ), driven by Qatar which had the largest sharks, with no significant size difference between Mozambique and Tanzania (Nemenyi test Qatar-Mozambique: $\mathrm{p}<0.001$, Qatar-Tanzania: $\mathrm{p}<0.001$, MozambiqueTanzania $\mathrm{p}=1$ ).

The Mozambican outlier point $\left(\delta^{15} \mathrm{~N}=7.29 \%\right.$ and $\delta^{13} \mathrm{C}=-18.5 \%$ o) was a juvenile male shark with whaleshark.org shark ID number MZ-587 and an estimated TL of $500 \mathrm{~cm}$. This individual has only 1 sample in this study. He had 7 encounters logged on Wildbook between 2011 and the end of the study period, spread evenly throughout this time. Interestingly, he had been spotted $200 \mathrm{~km}$ north of Tofo in Vilankulos.

The 2 Qatari outliers were a female with an estimated TL of $700 \mathrm{~cm}$ with whaleshark.org shark ID number Q-128 $\left(\delta^{15} \mathrm{~N}=8.73 \%\right.$ and $\delta^{13} \mathrm{C}=-14.7 \%$ ) and a juvenile male with an estimated TL of $500 \mathrm{~cm}$ $\left(\delta^{15} \mathrm{~N}=11.17 \%\right.$ and $\delta^{13} \mathrm{C}=-14.47 \%$ ). The female had only been recorded once in Al Shaheen. The male had been recoded 3 times between 2011 and 2012. All the outlier sharks had $\delta^{15} \mathrm{~N}$ values within $2 \mathrm{SD}$ of the mean for their location.

\section{Stable isotopes across latitude}

$\delta^{15} \mathrm{~N}$ values generally increase with decreasing latitude in barnacles, tuna, and sampled whale sharks. However, datasets are incomplete, and the apparent latitudinal trends could reflect a relatively abrupt

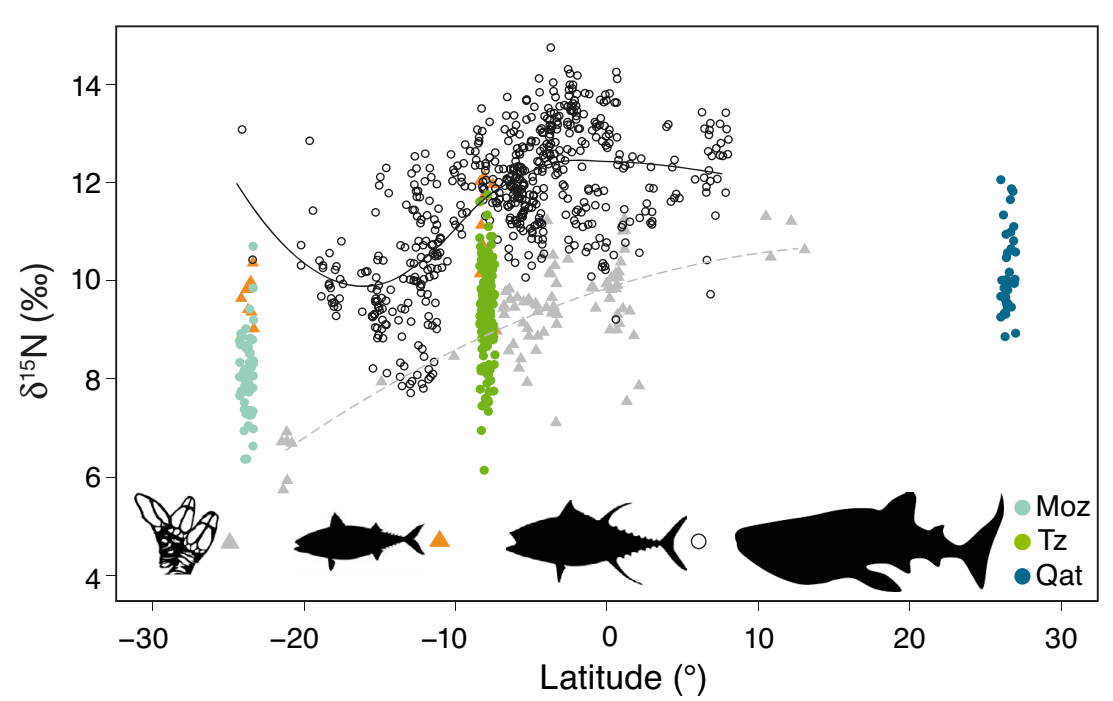

Fig. 5. $\delta^{15} \mathrm{~N}$ values by latitude. All whale shark (closed coloured circles) and planktivore (orange triangles) values are from this study, tuna data (black open circles) are from Sardenne et al. (2016), and barnacle data (grey triangles) are from Lorrain et al. (2015). Second-order polynomial models are plotted through barnacle data (dashed grey line) and a loess smoother is plotted through tuna data (solid black line) 


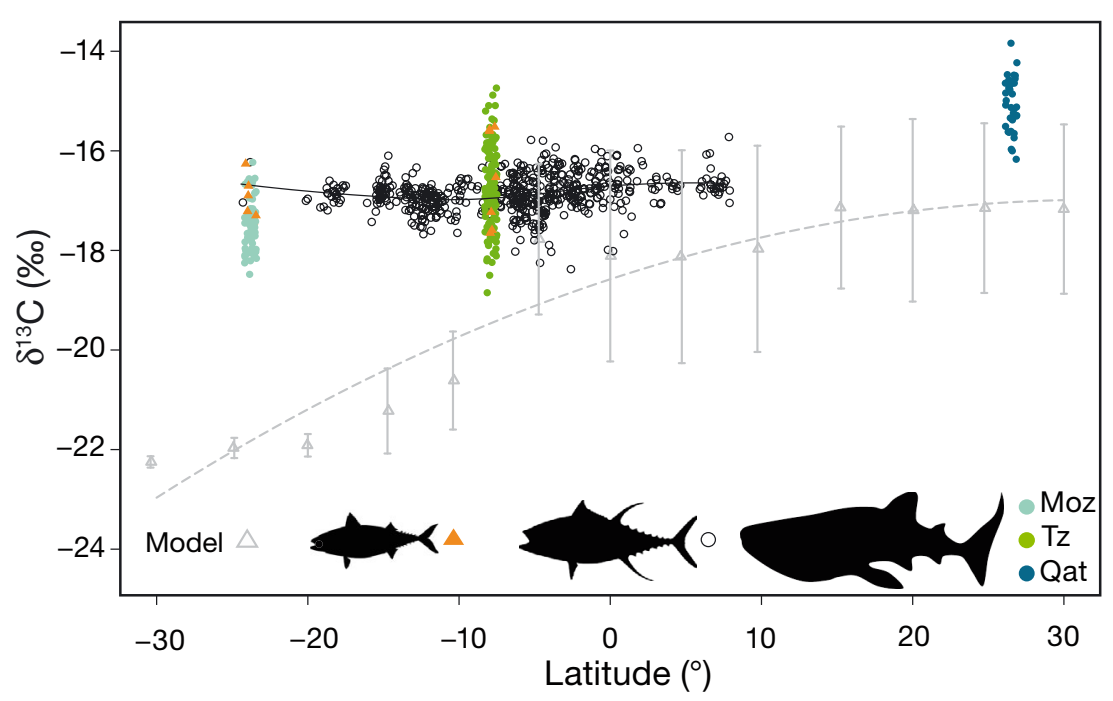

Fig. 6. $\delta^{13} \mathrm{C}$ values by latitude. All whale shark (closed coloured circles) and planktivore (orange triangle) values are from this study, tuna data (black open circles) are from Sardenne et al. (2016), and $\delta^{13} \mathrm{C}$ model output data (mean $\pm \mathrm{SD}$; grey triangles) are from (Magozzi et al. 2017). Second-order polynomial models are plotted through model $\delta^{13} \mathrm{C}$ data (dashed grey line) and a loess smoother plotted through tuna data (solid black line) transition to relatively high and invariant $\delta^{15} \mathrm{~N}$ values north of around $10^{\circ} \mathrm{S}$ (Fig. 5).

$\delta^{13} \mathrm{C}$ values estimated from a isotope-enabled global biogeochemical model show a similar abrupt increase at around $10^{\circ} \mathrm{S}$, approximately indicating the transition from South Indian Ocean and Arabian Sea surface waters. Neither tuna nor whale shark data reflect the predicted changes in phytoplankton $\delta^{13} \mathrm{C}$ values (Fig. 6), both fish groups showing relatively limited latitudinal variation in $\delta^{13} \mathrm{C}$ values.

There is a similar overall trend for gradual enrichment of $\delta^{15} \mathrm{~N}$ and $\delta^{13} \mathrm{C}$ values with increasing latitude, with a less pronounced gradient for $\delta^{13} \mathrm{C}$ values (Figs. $5 \& 6$ ).

\section{DISCUSSION}

Whale sharks are undoubtedly capable of making large ocean-scale movements (Hueter et al. 2013, Norman et al. 2017). However, our results from the Western Indian Ocean are consistent with other whale shark aggregations dominated by juvenile and adult males showing little evidence of broad-scale dispersal or connectivity between distant feeding sites (Norman et al. 2017). Differentiation between study sites was shown over a $10 \mathrm{yr}$ time-frame for photo-ID, and 2 to 3 yr for SIA. While modelled shark movement at all 3 sites was characterised by emigration and re-immigration, with some mortality or permanent emigration, a significant proportion of individual sharks displayed feeding site fidelity (Chapman et al. 2015, Robinson et al. 2017). Values for both $\delta^{15} \mathrm{~N}$ and $\delta^{13} \mathrm{C}$ differentiated each study site, despite some individual variability within the results.
Although both $\delta^{13} \mathrm{C}$ and $\delta^{15} \mathrm{~N}$ enriched with larger estimated total length, as this parameter was not independent of study site, we do not have enough data to draw any inferences from this result. The observed ellipse overlap between sharks from Mozambique and Tanzania indicates that sharks are exposed to similar isotopic conditions, making it impossible to test for regional mixing in the vicinity of the Mozambique Channel (Jackson et al. 2011), although only 2 sharks were observed moving between these sites following extensive survey effort at both locations. The lack of overlap between Mozambique and Qatar convex hull and ellipses, coupled with a lack of photo-ID re-sightings over this area, indicates that they are experiencing different isotopic conditions and appear to represent different functional populations for management purposes. Photo-ID results here and previous tagging results (Robinson et al. 2017) show no evidence of connectivity between Tanzania and Qatar, which suggests that the hull overlap between them is unlikely to represent shared individuals or resources. More likely this is a result of individual diet choice and the isotopic signatures of available prey producing similar integrated results in both locations.

Sharks from Tanzania had the largest variability in both $\delta^{15} \mathrm{~N}$ and $\delta^{13} \mathrm{C}$ and thus the broadest overall isotopic niche. Despite the relatively high site fidelity noted in the Tanzanian sharks, they still moved into slightly deeper water in the 'off' season (Cagua et al. 2015). Thus some of this variability is likely to come from foraging in different locations. However the range of $\delta^{13} \mathrm{C}$ isotope values seen in the Tanzanian sharks is as wide as the latitudinal changes predicted over the whole latitudinal range of the study (Magoz- 
zi et al. 2017). This suggests, based on our current knowledge of their movements, that the result could reflect a wider variety of isotopic feeding sources being available in the Mafia Island area, or more individual specialisation in prey types. While visual observations of feeding and surface sampling has documented that whale sharks feed on sergestid shrimp (Rohner et al. 2015a,b) and small baitfish (C. E. M. Prebble, C. A. Rohner \& S. J. Pierce pers. obs.), high-resolution tracking results suggest whale sharks switch to prey sources near the substrate at night (C. A. Rohner \& J. Paulsen unpubl. data).

Mozambican sharks were more mobile, with a residency time less than a third of that in Tanzania, double the emigration rate, and the steepest decline in LIR. Mozambique is one of the only large non-seasonal whale shark aggregations (Rohner et al. 2013), with local abundance at Tofo Beach relating at least in part to productivity (C. A. Rohner et al. unpubl.). Mozambican sharks had more enriched values for $\delta^{15} \mathrm{~N}$ and $\delta^{13} \mathrm{C}$ than the baseline barnacle data, or the $\delta^{13} \mathrm{C}$ model predictions. This suggests that the sharks in Mozambique are feeding either in more isotopically-enriched areas, or on more enriched prey sources. While photo-ID results reported in this study clearly indicate some linkage with South African waters, latitudinal isotope model predictions indicate that northern South African waters will be less enriched than those further north in the Mozambican Channel (Magozzi et al. 2017). The northern Mozambican Channel, in particular, is a notable hotspot for whale sharks (Sequiera et al. 2012). Movement to this region could contribute to the ellipse overlap observed between sharks from Mozambique and Tanzania, supporting a hypothesis of some broad-scale resource-sharing. However, results from dietary fatty acid studies in Mozambican sharks, supported by tracking studies (Brunnschweiler et al. 2009, Rohner et al. 2018), have indicated that they feed in deeper offshore waters (Rohner et al. 2013a). This could result in a similar level of isotopic enrichment (Graham et al. 2010). Both theories could also explain the highly enriched carbon value of the outlier shark from Mozambique if he had recently arrived in the study site from extended deep sea or offshore feeding. A further, more detailed isotopic investigation of the local and mesopelagic food web in Mozambican waters would be needed to clarify this result.

Qatar is a highly seasonal feeding aggregation (Robinson et al. 2013) with sharks staying for several months during the peak season (Robinson et al. 2017 ), and a high mean re-sight rate (41\%) of individuals among seasons (Robinson et al. 2016). The sharks disperse from the Al Shaheen area outside the tuna spawning season (Robinson et al. 2013, 2016, 2017). Movement model estimates and isotope values obtained in this study further support these previous results. Borrell et al. (2011) used muscle biopsies from whale sharks in Veraval, India, to investigate isotope ecology in northern Indian Ocean area. Using our tissue enrichment value $\left(2.5 \% \delta^{13} \mathrm{C}\right)$ the Borrell et al. (2011) values span a corrected range of $-12.2 \%$ to $-15.4 \%$; values similar to the raw bulk results for Qatar, which lies at a similar latitude to Veraval, India, and fall in line with the established $\delta^{13} \mathrm{C}$ latitude gradient (Magozzi et al. 2017).

However, the Borrell et al. (2011) $\delta^{15} \mathrm{~N}$ values are more enriched than any found in this study. Borrell et al. (2011) observed that all species in their study had high $\delta^{15} \mathrm{~N}$, possibly due to high organic pollution. We suggest that the high denitrification in the Arabian Sea (Sokoll et al. 2012, Gaye et al. 2013) could also result in the observed $\delta^{15} \mathrm{~N}$ enrichment. If the sharks seen in the Arabian Gulf did indeed make frequent feeding forays into the Arabian Sea, undetected by electronic tagging or photo-ID, we would expect them to have $\delta^{15} \mathrm{~N}$ values closer to those recorded from sharks captured in India. The large observed difference between $\delta^{15} \mathrm{~N}$ of the 2 locations suggests this is not occurring with any regularity.

The comparatively enriched $\delta^{13} \mathrm{C}$ values of 2 Qatari outlier sharks suggest they had been feeding in different isotopic conditions. This raises the possibility that these sharks had recently come from outside the Arabian Gulf before sampling occurred. Electronic tagging shows sharks predominantly resident to the Arabian Gulf year-round, yet some do venture through the Strait of Hormuz to the Gulf of Oman and beyond, with 1 female travelling as far as Somalia (Robinson et al. 2017). Smaller ( 5 m) whale sharks are not common in Qatar and potentially have different habitats to the larger mature sharks as they are mostly seen in more coastal areas and into the Gulf of Oman (Robinson et al. 2016, 2017).

Determining the time frame over which stable isotopes are assimilated (the tissue turnover rate) is challenging. Turnover rate refers to the time taken to completely replace a specific tissue pool, in this case to replace connective tissue proteins. These rates are tissue-specific, species-specific and probably even individual-specific, so they need to be estimated in controlled feeding experiments (Wolf et al. 2009, Logan \& Lutcavage 2010b, Kim et al. 2012b). The large size and Endangered conservation status of whale sharks (Pierce \& Norman 2016) creates complex logistical, ethical, and financial challenges for 
whale shark husbandry (Leu et al. 2015, Dove et al. 2011), meaning long-term controlled feeding studies for whale sharks are unlikely to take place. Few controlled feeding studies have been conducted in elasmobranchs, with most focussing on muscle, liver and blood tissues rather than the dermal connective tissue we collected from whale shark biopsies (MacNeil et al. 2005, Hussey et al. 2010, Logan \& Lutcavage 2010a, Kim et al. 2012b). The turnover rate of dermal connective tissue would be determined by the replacement of epithelial cells in the outer layers, and metabolic tissue replacement internally. In chondrichthyans the epidermis (including placoid scales or denticles in sharks) is a continuously metabolically active layer that protects them from the environment, and cell turnover occurs through damage, cell shedding, and regrowth (Meyer \& Seegers 2012). Consequently, isotopic incorporation is likely relatively fast, perhaps a few weeks. In elasmobranchs, deeper layers of the dermis also have strong mechanical capabilities and are composed of numerous collagen fibre bundles, only the deeper layers of the hypodermis are highly vascularised (Meyer \& Seegers 2012), suggesting that the outer epithelial cells have slower cell turnover, replacement, and isotopic incorporation rates, perhaps a by few months (Martínez del Rio et al. 2009).

Initial scarring studies support these inferred turnover rates, demonstrating whale sharks' maximum healing times from deep skin lacerations over a few months (Womersley et al. 2016). As we used tissue close to the outer epidermal layers in this study, we predict that the results here represent nearer a few weeks of integrated foraging.

The broadly enriching trend of all the groups in the $\delta^{15} \mathrm{~N}$ latitudinal plot suggests the differences in $\delta^{15} \mathrm{~N}$ values among study sites are at least in part driven by, and reflect, the baseline $\delta^{15} \mathrm{~N}$ in the local environment. However, some of the tuna caught in lower latitudes did not display the predicted baseline $\delta^{15} \mathrm{~N}$. This could partly be a result of the distribution of tuna data, as there were fewer samples from these latitudes included in the model. Sampling methodology may also affect the variation, as the coordinates assigned to each sample were the mean of up to a $5^{\circ}$ square. In addition, the tuna are highly mobile. Though a tuna was caught in the latitudes below $-15^{\circ}$ (Fig. 5), this does not preclude the possibility that it had recently been feeding at more isotopically enriched latitudes. Using a fourth-order polynomial to fit these data is not ideal and reduces the analytical power of the model applied to the data. However, it does correctly represent the discrepancy observed at the lower latitudes. While the tuna data are, therefore, not a perfect proxy dataset for latitudinal variation in the isoscapes, this is the most complete dataset available for this large region. Tuna are a highly mobile group. As a relative measure the comparison with whale shark data indicates that whale sharks, which show less variation, are less mobile than the tuna.

While this study only considers 3 of the several known whale shark aggregations in the Indian Ocean, broader photo-ID studies (Brooks et al. 2010, Andrzejaczek et al. 2016, Norman et al. 2017) have similarly found minimal evidence for connectivity of juvenile and sub-adult whale sharks among coastal aggregations in the region, although Andrzejaczek et al. (2016) noted the high sampling effort required to state this with confidence. Sequeira et al. (2013) also postulated that separate whale shark subpopulations, respectively, may exist in (1) the southern and central Western Indian Ocean, and (2) the northern Western Indian Ocean and Arabian Sea region. Low connectivity has also been identified in other large marine species in the region. Indian Ocean humpback dolphin (formerly Sousa chinensis, now S. plumbea; Jefferson \& Rosenbaum 2014) populations in Oman, Tanzania and Mozambique showed significant differences in mitochondrial DNA, with this divergence hypothesised to be a consequence of partial oceanographic isolation (Mendez et al. 2011). The South Equatorial Current tracks westwards across the Indian Ocean, splitting into northbound and southbound coastal flows when it hits northern Madagascar and then the African continent at approximately $10^{\circ} \mathrm{S}$, creating environmental differences between marine habitats off Mozambique and Tanzania (Mendez et al. 2011); this is a likely driver of the model $\delta^{13} \mathrm{C}$ differences around $10^{\circ} \mathrm{S}$. The resolution of whale shark population structure in this region would be facilitated by sampling adult sharks, which have been previously tagged in offshore waters (Sequeira et al. 2012, Escalle et al. 2016) and higher-resolution genetic or genomic studies. Until then, the results of this study imply that the dispersal of juvenile whale sharks from coastal feeding areas is limited by oceanographic boundaries in the Western Indian Ocean.

\section{Conservation and management implications}

Whale sharks were reclassified as globally Endangered by the IUCN in 2016 (Pierce \& Norman 2016), with the Indian Ocean subpopulation also being Endangered. A regional IUCN Red List assessment 
for whale sharks in the Arabian Sea region also classified the species as Endangered in that area in 2017 (Pierce \& Norman 2016, Jabado et al. 2017). Whale sharks in the Arabian Gulf and the Gulf of Oman also face threats from busy shipping lanes (Reynolds 1993) and several other anthropogenic threats (Robinson 2016), including a small opportunistic fishery active in Oman (Robinson unpubl. data). Smallscale harpoon and entanglement fisheries for whale sharks have taken place in several other countries, such as Iran and Pakistan (Rowat \& Brooks 2012). As even the larger, adult male sharks show some residency or site fidelity to the Arabian Gulf and Gulf of Oman (Robinson et al. 2016, 2017), these impacts will have a disproportionate effect on what may be a small shark population (Pierce \& Norman 2016, Robinson et al. 2016).

Whale sharks in Tanzania and Mozambique also face differing anthropogenic threats. A high proportion of Mafia Island sharks bear scars from interactions with fisheries (C. A. Rohner unpubl. data). While no population trend data are available from East African waters, further south in the northern Mozambique Channel there was an approximately $50 \%$ decline in peak monthly whale shark sightings from tuna observers between 1991 and 2007 (Sequeira et al. 2014). In Inhambane, Mozambique, in the southern Mozambique Channel, sightings declined $79 \%$ between 2005 and 2011 (Rohner et al. 2013a), and increasing gillnet use along this coast is thought to have a significant negative impact on megafauna sightings (Rohner et al. 2018)

The current view of whale shark population structure in the Indo-Pacific is that the area can be regarded as a single panmictic management unit. Here we have shown that the range of juvenile sharks is more locally restricted, with oceanographic barriers having a significant influence on dispersal. Relatively localised human threats may have a more pronounced impact on whale sharks than was previously recognised.

Ethics statement. Work in Mozambique was carried out with the full knowledge and approval of the Maputo Natural History Museum. All samples from Mozambique were exported (CITES Export MZ0260/16, and permission from the Maputo Natural History Museum), transported (APB Ref: U1246053/ APB/OTHER) and imported (CITES Import 550360/01, DEFRA Authorisation No: ITIMP16/1049) into the UK for analysis. In Qatar work was approved by, and carried out in conjunction with, Qatar Ministry of Municipality and Environment (QMMOE). Work in Tanzania was conducted with approval from the Tanzanian Commission for Science and Technology (COSTECH) (\#2015-165/6-NA-2015-161). All samples from Tanzania were exported (CITES Export \#30015
/Special export licence Fisheries Development Division) and imported (CITES Import \#552057/01) into the UK under the same APB/DEFRA licences as Mozambican samples. Project ethics approval came from the Research and Governance Department at the University of Southampton (\#13918).

Acknowledgements. We thank everyone at the Marine Megafauna Foundation and the whale shark research team at King Abdullah University of Science and Technology, and the Tanzanian Fisheries Institute for carrying out fieldwork and contributing to both the photo-ID data and sample collection. We thank everyone involved in the Qatar Whale Shark Research Project, as well as the staff at the Qatar Ministry of Municipality and Environment (QMME), and the Qatar Coast Guard for providing the platform to carry out field research in Qatar. We thank the North Oil Company in Qatar for their support and for joining the Qatar Whale Shark Research project as the new operator of the Al Shaheen oil field. We also thank the World Wide Fund for Nature Tanzania, Shark Foundation, Aqua-Firma, Rufford Small Grants, Waterlust, and the PADI Foundation, for their support of this project. Special personal thanks to Baraka Kuguru and Mathias Igulu for their help with Tanzanian permits, Jason Rubens and Haji Machano for facilitating the project, and Liberatus Mokoki for his expertise on the water. S.J.P. and C.A.R. were supported by 2 private trusts. In Mozambique we also thank Peri-Peri Divers and Casa Barry Lodge for providing logistical support and All Out Africa and Underwater Africa for contributing to the photo-ID data. We thank Dr. Peter Corkeron and the 2 anonymous reviewers for their helpful comments.

\section{LITERATURE CITED}

Akhilesh KV, Shanis CPR, White WT, Manjebrayakath H and others (2013) Landings of whale sharks Rhincodon typus Smith, 1828 in Indian waters since protection in 2001 through the Indian Wildlife (Protection) Act, 1972. Environ Biol Fishes 96:713-722

Alava MNR, Dolumbaló ERZ, Yaptinchay AA, Trono RB (2002) Fishery and trade of whale sharks and manta rays in the Bohol Sea, Philippines. In: Fowler SL, Reed TM, Dipper FA (eds) Elasmobranch biodiversity, conservation and management: Proceedings of the international seminar and workshop, Sabah, Malaysia, July 1997. IUCN Shark Specialist Group, p 132-148

Anderson C, Waheed A (2001) The economics of shark and ray watching in the Maldives. Shark News 13:1-3

Andrzejaczek S, Meeuwig J, Rowat D, Pierce S, Davies T, Fisher R, Meekan M (2016) The ecological connectivity of whale shark aggregations in the Indian Ocean: a photo-identification approach. R Soc Open Sci 3:160455

* Arzoumanian Z, Holmberg J, Norman B (2005) An astronomical pattern-matching algorithm for computer-aided identification of whale sharks Rhincodon typus. J Appl Ecol 42:999-1011

Berumen ML, Braun CD, Cochran JEM, Skomal GB, Thorrold SR (2014) Movement patterns of juvenile whale sharks tagged at an aggregation site in the Red Sea. PLOS ONE 9:e103536

Borrell A, Aguilar A, Gazo M, Kumarran RP, Cardona L (2011) Stable isotope profiles in whale shark (Rhincodon typus) suggest segregation and dissimilarities in the diet 
depending on sex and size. Environ Biol Fishes 92: 559-567

Brooks K, Rowat D, Pierce SJ, Jouannet D, Vely M (2010) Seeing Spots: photo-identification as a regional tool for whale shark identification study area. West Indian Ocean J Mar Sci 9:185-194

Brunnschweiler JM, Baensch H, Pierce SJ, Sims DW (2009) Deep-diving behaviour of a whale shark Rhincodon typus during long-distance movement in the western Indian Ocean. J Fish Biol 74:706-714

Buckland ST, Garthwaite PH (1991) Quantifying precision of mark-recapture estimates using the bootstrap and related methods. Biometrics 47:255-268

*Burgess KB, Bennett MB (2017) Effects of ethanol storage and lipid and urea extraction on $\delta^{15} \mathrm{~N}$ and $\delta^{13} \mathrm{C}$ isotope ratios in a benthic elasmobranch, the bluespotted maskray Neotrygon kuhlii. J Fish Biol 90:417-423

Cagua EF, Collins N, Hancock J, Rees R (2014) Whale shark economics: a valuation of wildlife tourism in South Ari Atoll, Maldives. PeerJ 2:e515

Cagua EF, Cochran JEM, Rohner CA, Prebble CEM, Sinclair-Taylor TH, Pierce SJ, Berumen ML (2015) Acoustic telemetry reveals cryptic residency of whale sharks. Biol Lett 11:20150092

Chapman DD, Feldheim KA, Papastamatiou YP, Hueter RE (2015) There and back again: a review of residency and return migrations in sharks, with implications for population structure and management. Annu Rev Mar Sci 7: $547-570$

Ciach M (2015) Rapid decline of an isolated population of the black grouse Tetrao tetrix: the crisis at the southern limit of the range. Eur J Wildl Res 61:623-627

Cliff G, Anderson-Reade MD, Aitken AP, Charter GE, Peddemors VM (2007) Aerial census of whale sharks (Rhincodon typus) on the northern KwaZulu-Natal coast, South Africa. Fish Res 84:41-46

Clingham E, Webb HD, da la Parra Venegas R, Schreiber C and others (2016) Further evidence of the importance of St. Helena as habitat for whale sharks. QScience Proc (4th Int Whale Shark Conf) 2016:iwsc4.11

* Cochran JEM, Hardenstine RS, Braun CD, Skomal GB and others (2016) Population structure of a whale shark Rhincodon typus aggregation in the Red Sea. J Fish Biol 89: 1570-1582

Couturier LIE, Rohner CA, Richardson AJ, Marshall AD and others (2013) Stable isotope and signature fatty acid analyses suggest reef manta rays feed on demersal zooplankton. PLOS ONE 8:e77152

Davis D, Banks S, Birtles A, Valentine P, Cuthill M (1997) Whale sharks in Ningaloo Marine Park: managing tourism in an Australian marine protected area. Tour Manage 18:259-271

de la Torre JA, Núñez JM, Medellín RA (2016) Habitat availability and connectivity for jaguars (Panthera onca) in the Southern Mayan Forest: Conservation priorities for a fragmented landscape. Biol Conserv 206:270-282

Dove AM, Coco C, Binder T, Schreiber C, Davis R, Carlson B, Clauss TM (2011) Acquisition, husbandry and veterinary care of whale sharks in a public aquarium setting. In: Cipriano R, Schelkunov I (eds) Health and diseases of aquatic organisms: bilateral perspectives. Proceedings of the 3rd US/Russian Bilateral Exchange on Aquatic Animal Health. MSU Press, East Lansing, p 251-258

Dubois M, Rossi V, Ser-Giacomi E, Arnaud-Haond S, López C, Hernández-García E (2016) Linking basin-scale con- nectivity, oceanography and population dynamics for the conservation and management of marine ecosystems. Glob Ecol Biogeogr 25:503-515

Escalle L, Pennino MG, Gaertner D, Chavance P and others (2016) Environmental factors and megafauna spatio-temporal co-occurrence with purse-seine fisheries. Fish Oceanogr 25:433-447

Fox S, Foisy I, De La Parra Venegas R, Galván Pastoriza BE and others (2013) Population structure and residency of whale sharks Rhincodon typus at Utila, Bay Islands, Honduras. J Fish Biol 83:574-587

* Gaye B, Nagel B, Dähnke K, Rixen T, Emeis KC (2013) Evidence of parallel denitrification and nitrite oxidation in the ODZ of the Arabian Sea from paired stable isotopes of nitrate and nitrite. Global Biogeochem Cycles 27: 1059-1071

Graham BS, Koch PL, Newsome SD, McMahon KW, Aurioles D (2010) Using isoscapes to trace the movements and foraging behavior of top predators in oceanic ecosystems. In: West JB, Bowen GJ, Dawson TE, Tu KP (eds) Isoscapes: understanding movement, pattern, and process on Earth through isotope mapping. Springer Netherlands, Dordrecht, p 299-318

Graham RT, Roberts CM (2007) Assessing the size, growth rate and structure of a seasonal population of whale sharks (Rhincodon typus Smith 1828) using conventional tagging and photo identification. Fish Res 84:71-80

* Haskell PJ, McGowan A, Westling A, Méndez-Jiménez A and others(2015) Monitoring the effects of tourism on whale shark Rhincodon typus behaviour in Mozambique. Oryx 49:492-499

Hays GC, Ferreira LC, Sequeira AMM, Meekan MG and others (2016) Key questions in marine megafauna movement ecology. Trends Ecol Evol 31:463-475

*Hobson KA (1999) Tracing origins and migration of wildlife using stable isotopes: a review. Oecologia 120:314-326

*Holmberg J, Norman B, Arzoumanian Z (2009) Estimating population size, structure, and residency time for whale sharks Rhincodon typus through collaborative photoidentification. Endang Species Res 7:39-53

${ }^{*} H s u$ HH, Joung SJ, Liu KM (2012) Fisheries, management and conservation of the whale shark Rhincodon typus in Taiwan. J Fish Biol 80:1595-1607

Hueter RE, Tyminski JP, de la Parra R (2013) Horizontal movements, migration patterns, and population structure of whale sharks in the Gulf of Mexico and northwestern Caribbean sea. PLOS ONE 8:e71883

*Hussey NE, Brush J, McCarthy ID, Fisk AT (2010) $\delta^{15} \mathrm{~N}$ and $\delta^{13} \mathrm{C}$ diet-tissue discrimination factors for large sharks under semi-controlled conditions. Comp Biochem Physiol A Mol Integr Physiol 155:445-453

Hussey NE, MacNeil MA, Olin JA, McMeans BC, Kinney MJ, Chapman DD, Fisk AT (2012a) Stable isotopes and elasmobranchs: tissue types, methods, applications and assumptions. J Fish Biol 80:1449-1484

*Hussey NE, Olin JA, Kinney MJ, McMeans BC, Fisk AT (2012b) Lipid extraction effects on stable isotope values $\left(\delta^{13} \mathrm{C}\right.$ and $\left.\delta^{15} \mathrm{~N}\right)$ of elasmobranch muscle tissue. J Exp Mar Biol Ecol 434-435:7-15

Jabado RW, Kyne PM, Pollom RA, Ebert DA, Simpfendorfer CA, Ralph GM, Dulvy NK (2017) The conservation status of sharks, rays and chimeras in the Arabian Sea and adjacent waters. Environment Agency Abu Dhabi, UAE and IUCN Species Survival Commission Specialist Group, Vancouver 
Jackson AL, Inger R, Parnell AC, Bearhop S (2011) Comparing isotopic niche widths among and within communities: SIBER - stable isotope Bayesian ellipses in R. J Anim Ecol 80:595-602

Jefferson TA, Rosenbaum HC (2014) Taxonomic revision of the humpback dolphins (Sousa spp.), and description of a new species from Australia. Mar Mamm Sci 30:1494-1541

Johnson CJ, Ehlers LPW, Seip DR (2015) Witnessing extinction-Cumulative impacts across landscapes and the future loss of an evolutionarily significant unit of woodland caribou in Canada. Biol Conserv 186:176-186

Jonahson M, Harding S (2007) Occurrence of whale sharks (Rhincodon typus) in Madagascar. Fish Res 84:132-135

* Jones T, Wood D, Catlin J, Norman B (2009) Expenditure and ecotourism: predictors of expenditure for whale shark tour participants. J Ecotour 8:32-50

Juinio-Meñez MA (2015) Biophysical and genetic connectivity considerations in marine biodiversity conservation and management in the South China Sea. J Int Wildl Law Policy 18:110-119

Kiljunen M, Grey J, Sinisalo T, Harrod C, Immonen H, Jones RI (2006) A revised model for lipid-normalizing $\delta^{13} \mathrm{C}$ values from aquatic organisms, with implications for isotope mixing models. J Appl Ecol 43:1213-1222

Kim SL, Koch PL (2012) Methods to collect, preserve, and prepare elasmobranch tissues for stable isotope analysis. Environ Biol Fishes 95:53-63

Kim SL, Casper DR, Galván-Magaña F, Ochoa-Díaz R, Hernández-Aguilar SB, Koch PL (2012a) Carbon and nitrogen discrimination factors for elasmobranch soft tissues based on a long-term controlled feeding study. Environ Biol Fishes 95:37-52

Kim SL, Martínez del Rio C, Casper D, Koch PL (2012b) Isotopic incorporation rates for shark tissues from a longterm captive feeding study. J Exp Biol 215:2495-2500

Leu MY, Li JJ, Ju YM, Hsiao CM and others (2015) Transportation, husbandry, and release of a whale shark ('Rhincodon typus'). J Mar Sci Technol 23:814-818

Li Y, Hussey NE, Zhang Y (2016) Quantifying ontogenetic stable isotope variation between dermis and muscle tissue of two pelagic sharks. Aquat Biol 25:53-60

Lima M, Marquet PA, Jaksic FM (1996) Extinction and colonization processes in subpopulations of five neotropical small mammal species. Oecologia 107:197-203

Logan JM, Lutcavage ME (2010a) Stable isotope dynamics in elasmobranch fishes. Hydrobiologia 644:231-244

Logan JM, Lutcavage ME (2010b) Reply to Hussey et al.: The requirement for accurate diet-tissue discrimination factors for interpreting stable isotopes in sharks. Hydrobiologia 654:7-12

Lorrain A, Graham BS, Popp BN, Allain V and others (2015) Nitrogen isotopic baselines and implications for estimating foraging habitat and trophic position of yellowfin tuna in the Indian and Pacific Oceans. Deep-Sea Res II 113:188-198

MacNeil MA, Skomal GB, Fisk AT (2005) Stable isotopes from multiple tissues reveal diet switching in sharks. Mar Ecol Prog Ser 302:199-206

Magozzi S, Yool A, Vander Zanden HB, Wunder MB, Trueman CN (2017) Using ocean models to predict spatial and temporal variation in marine carbon isotopes. Ecosphere 8:e01763

Marcus L, Virtue P, Nichols PD, Meekan MG, Pethybridge H (2017) Effects of sample treatment on the analysis of stable isotopes of carbon and nitrogen in zooplankton, micronekton and a filter-feeding shark. Mar Biol 164:124

* Marshall AD, Pierce SJ (2012) The use and abuse of photographic identification in sharks and rays. J Fish Biol 80: 1361-1379

* Martínez del Rio C, Wolf N, Carleton SA, Gannes LZ (2009) Isotopic ecology ten years after a call for more laboratory experiments. Biol Rev Camb Philos Soc 84:91-111

*McMahon KW, Fogel ML, Elsdon TS, Thorrold SR (2010) Carbon isotope fractionation of amino acids in fish muscle reflects biosynthesis and isotopic routing from dietary protein. J Anim Ecol 79:1132-1141

*McMahon KW, Hamady LL, Thorrold SR (2013) A review of ecogeochemistry approaches to estimating movements of marine animals. Limnol Oceanogr 58:697-714

* Mendez M, Subramaniam A, Collins T, Minton G and others (2011) Molecular ecology meets remote sensing: environmental drivers to population structure of humpback dolphins in the Western Indian Ocean. Heredity 107: 349-361

* Meyer W, Seegers U (2012) Basics of skin structure and function in elasmobranchs: a review. J Fish Biol 80: 1940-1967

* Motta PJ (2012) Anatomy and functional morphology of dermal collagen fibers in sharks. Copeia 1977:454-464

* Norman BM, Holmberg JA, Arzoumanian Z, Reynolds SD and others (2017) Undersea constellations: The global biology of an Endangered marine megavertebrate further informed through citizen science. Bioscience 67: 1029-1043

Pierce SJ, Norman B (2016) Rhinocodon typus. The IUCN Red List of Threatened Species 2016:e.T19488A2365291

* Pierce SJ, Méndez-Jiménez A, Collins K, Rosero-Caicedo M, Monadjem A (2010) Developing a code of conduct for whale shark interactions in Mozambique. Aquat Conserv 20:782-788

*Post DM, Layman CA, Arrington DA, Takimoto G, Quattrochi J, Montaña CG (2007) Getting to the fat of the matter: models, methods and assumptions for dealing with lipids in stable isotope analyses. Oecologia 152:179-189

Pravin P (2000) Whale shark in the Indian coast-need for conservation. Curr Sci 79:310-315

R Core Team (2013) R: a language and environment for statistical computing. R Foundation for Statistical Computing, Vienna. www.R-project.org

* Ramírez-Macías D, Queiroz N, Pierce SJ, Humphries NE, Sims DW, Brunnschweiler JM (2017) Oceanic adults, coastal juveniles: tracking the habitat use of whale sharks off the Pacific coast of Mexico. PeerJ 5:e3271

* Reynolds RM (1993) Physical oceanography of the Gulf, Strait of Hormuz, and the Gulf of Oman-results from the Mt Mitchell expedition. Mar Pollut Bull 27:35-59

Riley MJ, Hale MS, Harman A, Rees RG (2010) Analysis of whale shark Rhincodon typus aggregations near South Ari Atoll, Maldives Archipelago. Aquat Biol 8:145-150

Robinson DP (2016) The ecology of whale sharks Rhincodon typus within the Arabian Gulf and the Gulf of Oman. PhD dissertation, Heriot Watt University, Edinburgh

Robinson DP, Jaidah MY, Jabado RW, Lee-Brooks K and others (2013) Whale Sharks, Rhincodon typus, aggregate around offshore platforms in Qatari waters of the Arabian Gulf to feed on fish spawn. PLOS ONE 8:e58255

Robinson DP, Jaidah MY, Bach S, Lee K and others (2016) Population structure, abundance and movement of whale sharks in the Arabian Gulf and the Gulf of Oman. PLOS ONE 11:e0158593 
Robinson DP, Jaidah MY, Bach SS, Rohner CA, Jabado RW, Ormond R, Pierce SJ (2017) Some like it hot: Repeat migration and residency of whale sharks within an extreme natural environment. PLOS ONE 12:e0185360

Rohner CA, Couturier LIE, Richardson AJ, Pierce SJ, Prebble CEM, Gibbons MJ, Nichols PD (2013a) Diet of whale sharks Rhincodon typus inferred from stomach content and signature fatty acid analyses. Mar Ecol Prog Ser 493: 219-235

Rohner CA, Pierce SJ, Marshall AD, Weeks SJ, Bennett MB, Richardson AJ (2013b) Trends in sightings and environmental influences on a coastal aggregation of manta rays and whale sharks. Mar Ecol Prog Ser 482:153-168

Rohner CA, Armstrong AJ, Pierce SJ, Prebble CEM and others (2015a) Whale sharks target dense prey patches of sergestid shrimp off Tanzania. J Plankton Res 37:352-362

Rohner CA, Richardson AJ, Prebble CEM, Marshall AD and others (2015b) Laser photogrammetry improves size and demographic estimates for whale sharks. PeerJ 3:e886

Rohner CA, Richardson AJ, Jaine FRA, Bennett MB and others (2018) Satellite tagging highlights the importance of productive Mozambican coastal waters to the ecology and conservation of whale sharks. PeerJ 6:e4161

Rowat D, Brooks KS (2012) A review of the biology, fisheries and conservation of the whale shark Rhincodon typus. J Fish Biol 80:1019-1056

Rowat D, Speed CW, Meekan MG, Gore MA, Bradshaw CJA (2009) Population abundance and apparent survival of the Vulnerable whale shark Rhincodon typus in the Seychelles aggregation. Oryx 43:591-598

Rowat D, Brooks K, March A, McCarten C and others (2011) Long-term membership of whale sharks (Rhincodon typus) in coastal aggregations in Seychelles and Djibouti. Mar Freshw Res 62:621-627

Sardenne F, Bodin N, Chassot E, Amiel A and others (2016) Trophic niches of sympatric tropical tuna in the Western Indian Ocean inferred by stable isotopes and neutral fatty acids. Prog Oceanogr 146:75-88

Satterfield FR IV, Finney BP (2002) Stable isotope analysis of Pacific salmon: Insight into trophic status and oceanographic conditions over the last 30 years. Prog Oceanogr 53:231-246

Sequeira A, Mellin C, Rowat D, Meekan MG, Bradshaw CJA (2012) Ocean-scale prediction of whale shark distribution. Divers Distrib 18:504-518

Sequeira AMM, Mellin C, Meekan MG, Sims DW, Brad- shaw CJA (2013) Inferred global connectivity of whale shark Rhincodon typus populations. J Fish Biol 82: 367-389

Sequeira AMM, Mellin C, Fordham DA, Meekan MG, Bradshaw CJA (2014) Predicting current and future global distributions of whale sharks. Glob Chang Biol 20: 778-789

Sokoll S, Holtappels M, Lam P, Collins G, Schlüter M, Lavik G, Kuypers MMM (2012) Benthic nitrogen loss in the Arabian Sea off Pakistan. Front Microbiol 3:395

Speed CW, Meekan MG, Rowat D, Pierce SJ, Marshall AD, Bradshaw CJA (2008) Scarring patterns and relative mortality rates of Indian Ocean whale sharks. J Fish Biol 72:1488-1503

Trueman CN, MacKenzie KM, Palmer MR (2012) Identifying migrations in marine fishes through stable-isotope analysis. J Fish Biol 81:826-847

Trueman CN, MacKenzie KM, St John Glew K (2017) Stable isotope-based location in a shelf sea setting: accuracy and precision are comparable to light-based location methods. Methods Ecol Evol 8:232-240

Underwood AJ (1997) Experiments in ecology: their logical design and interpretation using analysis of variance. Cambridge University Press, Cambridge

Vignaud TM, Maynard JA, Leblois R, Meekan MG and others (2014) Genetic structure of populations of whale sharks among ocean basins and evidence for their historic rise and recent decline. Mol Ecol 23:2590-2601

Whitehead H (2001) Analysis of animal movement using opportunistic individual identifications: Application to sperm whales. Ecology 82:1417-1432

Whitehead H (2009) SOCPROG programs: analysing animal social structures. Behav Ecol Sociobiol 63:765-778

Wolf N, Carleton SA, Martínez del Rio C (2009) Ten years of experimental animal isotopes ecology. Funct Ecol 23: $17-26$

Womersley FC, Leblond ST, Rowat DRL (2016) Scarring instance and healing capabilities of whale sharks and possible implications. Q Science Proc (4th Int Whale Shark Conf) 2016:iwcs4.67

Worboys GL, Francis WL, Lockwood M (2010) Connectivity conservation management: A global guide. Earthscan, London

Ziegler JA, Dearden P, Rollins R (2016) Participant crowding and physical contact rates of whale shark tours on Isla Holbox, Mexico. J Sustain Tour 24:616-636 
Appendix. Model descriptions and relative QAIC/AIC values for all models for each site

\begin{tabular}{|c|c|c|}
\hline Model & Model description & \\
\hline \multicolumn{2}{|c|}{ Tanzania } & $\Delta \mathrm{AIC}$ \\
\hline A & Closed $(1 / \mathrm{a} 1=\mathrm{N})$ & 547.028 \\
\hline B & Closed $(\mathrm{a} 1=\mathrm{N})$ & 547.028 \\
\hline $\mathrm{C}$ & Emigration/mortality (a1 = emigration rate; $1 / \mathrm{a} 2=\mathrm{N}$ ) & 159.469 \\
\hline $\mathrm{D}$ & Emigration/mortality ( $\mathrm{a} 1=\mathrm{N} ; \mathrm{a} 2=$ mean residence time) & 159.469 \\
\hline $\mathrm{E}$ & Emigration + reimmigration & 105.703 \\
\hline $\mathrm{F}$ & $\begin{array}{l}\text { Emigration + reimmigration }(\mathrm{a} 1=\mathrm{N} \\
\mathrm{a} 2=\text { mean time in study area; } \mathrm{a} 3=\text { mean time out of study area) }\end{array}$ & 105.703 \\
\hline G & Emigration + reimmigration + mortality & 71.904 \\
\hline $\mathrm{H}$ & Emigration + reimmigration + mortality & 0 \\
\hline \multicolumn{2}{|c|}{ Mozambique } & $\triangle \mathrm{QAIC}$ \\
\hline A & Closed $(1 / \mathrm{a} 1=\mathrm{N})$ & 80748.064 \\
\hline B & Closed $(\mathrm{a} 1=\mathrm{N})$ & 1040.944 \\
\hline $\mathrm{C}$ & Emigration/mortality (a1 = emigration rate; $1 / \mathrm{a} 2=\mathrm{N})$ & 154.114 \\
\hline $\mathrm{D}$ & Emigration/mortality (a1 = $\mathrm{N}$; 2 = mean residence time) & 155.428 \\
\hline E & Emigration + reimmigration & 155.428 \\
\hline $\mathrm{F}$ & $\begin{array}{l}\text { Emigration }+ \text { reimmigration }(\mathrm{a} 1=\mathrm{N} ; \\
\mathrm{a} 2=\text { mean time in study area; } \mathrm{a} 3=\text { mean time out of study area) }\end{array}$ & 155.428 \\
\hline $\mathrm{G}$ & Emigration + reimmigration + mortality & 158.114 \\
\hline $\mathrm{H}$ & Emigration + reimmigration + mortality & 0 \\
\hline $\begin{array}{l}\text { Qatar } \\
\text { A }\end{array}$ & Closed $(1 / a 1=N)$ & $\begin{array}{l}\triangle \mathrm{QAIC} \\
9742.286\end{array}$ \\
\hline B & Closed $(\mathrm{a} 1$ = N) & 52.232 \\
\hline $\mathrm{C}$ & Emigration/mortality (a1 = emigration rate; $1 / \mathrm{a} 2=\mathrm{N})$ & 22.437 \\
\hline $\mathrm{D}$ & Emigration/mortality (a1 = $\mathrm{N}$; 2 = mean residence time) & 22.437 \\
\hline E & Emigration + reimmigration & 32.438 \\
\hline $\mathrm{F}$ & $\begin{array}{l}\text { Emigration }+ \text { reimmigration }(\mathrm{a} 1=\mathrm{N} ; \\
\mathrm{a} 2=\text { mean time in study area; } \mathrm{a} 3=\text { mean time out of study area) }\end{array}$ & 22.437 \\
\hline G & Emigration + reimmigration + mortality & 26.443 \\
\hline $\mathrm{H}$ & Emigration + reimmigration + mortality & 0 \\
\hline
\end{tabular}

Editorial responsibility: Peter Corkeron, Woods Hole, Massachusetts, USA
Submitted: January 22, 2018; Accepted: June 13, 2018

Proofs received from author(s): July 27, 2018 